\title{
Confraternities and Lay Leadership in Sixteenth-Century Liège
}

\section{HENRY DIETERICH}

In examining the place of lay leadership in the late Medieval Church, one might well begin with that acute observer of the nineteenth-century English church and society, Anthony Trollope. In The Vicar of Bullhampton, he has the hard-headed Lord Saint George explain to his father, the Marquis, the genesis of religious dissent:

We can't prevent it, because, in religion as in everything else, men like to manage themselves. This farmer or that tradesman becomes a dissenter because he can be somebody in the management of his chapel, and would be nobody in regard to the parish church. ${ }^{1}$

Our conventional picture of the Medieval church is one in which the laity and their organizations, including the confraternity, were almost as much at odds with the official structure as the gentry-dominated Establishment of the nincteenth century was with the lower-middle-class Nonconformist chapels. In regard to confraternities, this tendency is best represented by the statement by Gabriel Le Bras that has been adopted by many confraternity studies since. Le Bras's thesis, repeated and modified by subsequent historians, views the confraternity as a sort of substitute parish. Confraternities provided important support for the Church's activities. Le Bras writes:

But all the time the confraternity disturbed the Church by its natural independence and frequent disorders. It constitutes in the bosom of or above the legal parish a consensual parish, with its oratory, its clergy, its worship, its patrimony. Hence the competition of worship services, of funds, of influences. Hence conflicts with the pastor, with the parish council, always latent, which break out in epidemics. ${ }^{2}$ 
This thesis-that the confraternity formed a "consensual parish" in conflict with the legal one-does not seem initially unlikely. There are enough examples, from the eighth century onward, of suspicion of or opposition to confraternities by the hierarchy to demonstrate that conflict sometimes happened. Certainly there have been examples of conflicts between confraternities and their parishes up to the present time. Confraternities have also argued with religious houses that sponsored them, over such issues as the use of buildings and other facilities. ${ }^{3}$

Other observers have argued that the Medieval parish was weak and the confraternity strong. Building on Jacques Toussaert's evidence that parochial obligations enjoined by canon law were not well observed in Flanders at the end of the Middle Ages, ${ }^{4}$ John Bossy asserts that the Medieval Church "was not in actual fact a parochially-grounded institution." Confraternities, on the other hand, provided the real religious life of the people. In his more recent Christianity and the West, Bossy has developed his earlier observation that brotherhood constituted the principal mode of religious life during the Middle Ages. While he points out the parallels between parish and confraternity formation, he stresses their potential and actual conflict. 6

Modern examples exist to support the Le Bras thesis by analogy. In a study of the surviving village confraternitics in France, Martine Segalen cites several cases of conflict between parish clergy and confraternities. For example, in Avignon, penitential confraternities whose origins go back to the Middle Ages have recently been in conflict with the local parishes in an effort to preserve their existence and traditions. ${ }^{7}$ Here, as in several cases in Normandy, the application of the vernacular liturgy and other changes since the Second Vatican Council have threatened the traditional strength of confraternitics in a fashion similar to that discussed by Bossy for the period following the Council of Trent. ${ }^{8}$

The mere existence and popularity of confraternities, however, is not cnough to establish a nonparochial model for the Medieval Church. The number of funcral monuments in parish churches suggests that parishes, both urban and rural, continued to command loyalty from their members. Clearly the relationship between the confraternity and the parish must be more complex than a simple opposition of one to the other. The parish was the unit of organization that locally cmbodied the inclusive and hierarchical principle of the institutional Church; the confraternity embodied the individual aspirations of the laity and the tradition of special brotherhood. Somchow these two elements had to work together. 
The present study looks at one parish, Saint-Martin-en-Ile in Liège, at the end of the fifteenth century and the beginning of the sixteenth, to examine the role of its largest-for most of the period, its only-functioning confraternity. We shall see that from its founding the confraternity was closely tied to the parish. The activities of the confraternity supported the parish structure, and the lay leadership of the parish was drawn largely from the confraternity.

The example of Saint-Martin-en-Ile suggests that rather than being in opposition to the parish, the confraternity may well have been a way of integrating the model of brotherhood into the canonical structure. In Liège as elsewhere in late Medieval Europe, the confraternity was a regular parish institution, where the most religiously active among the laity could enjoy the special relation of brotherhood that was so central to their mentality and which is, after all, an essential ideal in the Christian tradition.

In a recent important essay, "The Christian Middle Ages as an Historiographical Problem," John Van Engen has hailed the appearance of studies of local religious life "that was neither learned nor extraordinary nor a vehicle of protest." 9 Of the parish in particular he writes:

The study of parochial organization, liturgy, confraternities, pastoralia, and so on will in time bring historians much closer to understanding "routine" religious life in the Middle Ages than the study of unusual instances, for example, of an isolated Cathar village, a holy dog, or an eccentric miller. ${ }^{10}$

This study of a parish and its confraternity is offered in the hope of coming to such an understanding.

The parish of Saint-Martin, known as Saint-Martin-en-Ilc to distinguish it from the collegiate church of Saint-Martin-en-Mont, was one of the largest of the twenty-five parishes of Liège. The parish was founded in the late tenth century under bishop Eracle to serve the lay community surrounding the collegiate church of Saint-Paul, which was begun under Eracle and completed under his successor, Notger. ${ }^{11}$

Etienne Hélin estimates the parish population in 1650 as between 2440 and 3080 persons. ${ }^{12}$ If the population of the city as a whole was, as has been estimated, one-half its 1650 level at the end of the fifteenth century, the population of Saint-Martin-en-Ile would have been between 1200 and 1500. Economically, this population ranged in status from the canons of Saint-Paul to the miserable inhabitants of the swampy islands behind the parish church. A wide variety of trades could be found here. The population 


\section{8 / Renaissance and Reformation}

was far from homogeneous, and included samples of all occupations and classes, partly because it was so large, and partly because its location favoured the establishment of all sorts of commerce.

The chapter of Saint-Paul, as founders, retained the titular rectorate with its tithes. To govern the parish, they appointed a permanent vicar or vestit. In addition to the vicar, the parish had a varicty of clerics and lay people serving in various capacities. The composition and duties of the parish staff and other officers was typical of parishes in Liège and elsewhere at the time. ${ }^{13}$ The parish clerk (marlier) was elected by the parishioners. At the end of the fifteenth century, the parish clerk was a married man, probably in minor orders. His duties involved serving at mass, singing the responses, and caring for the sacred vessels.

The chief lay officials of the parish were the churchwardens (mambours) elected by the heads of households in the parish. They were responsible for the finances of the parish, and with the vicar they appointed the chaplains. Other officers of the parish, who received salaries, included the compteur who kept the books and collected payments due; the sexton (fossier) who was also elected by the parish; a mambour ${ }^{14}$ or attorney who represented the parish in lawsuits; and a laundress (boweresse) who washed the altar linens.

In property transactions the churchwardens were aided by a cour des tenants, a group of substantial men of the parish before whom all reliefs and transfers of property held from the parish were approved and witnessed. ${ }^{15}$ In dealing with outside institutions, such as in an appearance before the échevins, the churchwardens, the compteur, and sometimes a professional attorney represented the parish.

The finances of the parish were based on income from real property, in the form of cens (denominated in money) and rentes (denominated in kind, usually grain). Some of this went directly to the pastor, the chaplains, or the parish clerk. The rest usually formed three funds of which the churchwardens had charge: the general fund or luminaire, the mass fund, and the poor fund. These funds were the responsibility of the churchwardens, who designated a compteur to collect and keep track of them.

Between 1450 and 1538, Saint-Martin had eight vicars, five of whom served in person. If to have the official pastor in residence is fortunate, Saint-Martin was blessed throughout most of this period, at least 61 of 88 years. Unfortunately we know little of these vicars besides their names. ${ }^{16}$ When the vicar did not reside, he was replaced by another priest, referred 
to as the "lieutenant du vestit." Usually he was one of the parish chaplains who received fixed salaries from the mass fund in return for saying anniversary masses. The number of chaplains at Saint-Martin varied from none in the 1470s, to three or four (besides the "lieutenant") in the 1480 s, to as many as nine in the $1520 \mathrm{~s}$ and $1530 \mathrm{~s} .{ }^{17}$

During the period between 1480 and 1540 , the parish contained a number of confraternities. One of these appears to have been inactive, indeed moribund. Another was founded in the 1530s and included members of other parishes and of religious houses in the neighborhood. The Confraternity of Our Lady was the only one that was active during the years between the sack of Lic̀ge by Charles the Bold, which devastated the city in 1468, and the last years of the Renaissance prince-bishop Erard de la Marck. We are fortunate in possessing a fairly complete record of this confraternity's accounts, including membership lists, for this period. ${ }^{18}$

The Confraternity of Our Lady and the Blessed Sacrament (to give its full name) was founded in the tradition of the Medieval devotional parish confraternity, shortly before the sack of Liège. It was originally two organizations, the Confraternity of Our Lady, founded in 1457, and the Confraternity of the Blessed Sacrament, founded in 1461, which were united in 1473. In the sixteenth century, the dedication to the Blessed Sacrament in its title gradually dropped out of use.

The rule and activities of the Confraternity of Our Lady resembled those of many similar organizations throughout Europe. The members paid dues, equal at the end of the fifteenth century to almost two days' wages for a skilled workman. They were required to attend funerals of fellow members as well as regular masses sponsored by the confraternity throughout the year. Once a year the confraternity held a banquet in connection with the main mass of the year at the feast of the Assumption and the election of officers.

The confraternity and the parish were linked by more than a shared building. The rule of the confraternity demonstrates the founders' loyalty to the parish, both by its language and by its specific provisions. As the confraternity developed, its activities benefitted the parish. Moreover, the official leadership, both clerical and lay, participated in the life and assisted the development of the confraternity. In particular, the most active lay leaders in the parish were members of the confraternity.

For the confraternity, either as separate organizations or as one, we have five versions of the rule. The latest of these, a version published in 1792 , 
represents the confraternity as "renouvelléc l'an 1736," and therefore will not concern the present discussion. ${ }^{19}$ The other four date from the period 1450-1540. The first three, dated 1457, 1461, and 1480, are very similar; 20 the fourth, dated 1529 , is significantly different. ${ }^{21}$ Rather than review the rules in detail, I will review a few points that demonstrate the close ties of the confraternity with the parish.

The prologue shared by the rules of 1457,1461 , and 1480 sets the tone of loyalty to the parish. The founders declare that they are founding the confraternity with the aid of divine grace out of desire to serve God, the blessed Virgin, and their patron St. Martin. The confraternity of Our Lady, in its original rule, is called the confraternity "de Nostre Damme \& de Sains Martin." The rulc of the original Blessed Sacrament confraternity uses the same language, and adds to the name the phrase "du sains Sacrement."

Throughout the rulc, St. Martin, the parish patron, is mentioned over and over again as "our blessed patron." In Liège as elsewhere, the patron saint of the parish was the personal patron of the parishioner. ${ }^{22}$ In wills, for example, testators regularly commend their souls to the protection, not of their name-saint, but of the patron of their parish. The Christian's standing before God depended on his relation to this saint, as his relation to the Church depended on his relation to the parish that bore his name.

As with many confraternitics, regular masses centering around its titular devotion constituted the principal devotional activities called for in the original rules. The Confraternity of Our Lady solemnized the feasts of the Blessed Virgin, principally the feast of her Assumption (15 August) with masses on the other Marian feasts. ${ }^{23}$ These masses were to be celebrated at the main altar of the church "in token of obedience" ("en representant obedience") to St. Martin, patron of the parish.

The Blessed Sacrament confraternity also held its principal mass at the main altar. This celcbration fell on the octave of Corpus Christi, because, the rule says, the feast itself is already occupied with the parish celcbration. The confraternity also sponsored the celcbration of a mass at the main altar of the church, every Thursday of the year, by the vicar or a priest of his choosing. The rule adds that the confreres can take part by carrying candles in the offertory at the parish mass on Corpus Christi, as well as in the procession. The 1461 rulc provides for any excess money that might accumulate. It must not, the framers warn, be expended, through ill counsel, "on gluttony or excess" ("par gourmanderic ne oultrequidenche"). Instead, 
the superfluous goods are to go to the parish, to be used according to the decision of the vicar and churchwardens.

Thus the provision of liturgical celcbrations in the original rules of the two confraternities placed them firmly in the parish system. St. Martin's place in the spirituality of the confraternitics corresponds to the seals of the vicar and churchwardens, which they attached to the original charters as a sign of approval. All clearly understood the signs of loyalty offered and accepted.

This loyalty had practical consequences. Not only does the 1461 rule provide for its extra income to go to the parish; the annual and weekly masses, like the special masses in the 1457 rule, take place at the main altar. This is more than symbolic. Each mass involved a payment to the celebrant and to the parish clerk who assisted. Since the main altar was under the control of the vicar, the rules give him the option of saying the masses-and receiving the income from them-himself.

Later changes and modifications in the confraternal rule and pattern of activity continued the intention to cooperate closely with the parish. The earliest decision is the merging of the two original confraternities into one. The sack of Liège in 1468 caused great damage to the church of Saint-Martin-en-Ile, and the confraternity chapels and possessions did not escape. As he and the churchwardens acted to help rebuild the parish, the vicar, Jehan Thomas, moved to strengthen the confraternities by uniting them. On Corpus Christi, 1473, by his "consent and express wish" they were united. To symbolize this union, four men-probably the masters of the two confraternities-marched behind one of the churchwardens in the offertory procession. ${ }^{24}$

At some point "before the wars," as the confraternity accounts put it, the confraternity began to provide oil for the lamp that burned day and night before the tabernacle containing the reserved Blessed Sacrament. ${ }^{25}$ For this purpose, the confraternity had acquired or received as a bequest a rente of four quarts of rapeseed oil. Since they both took and used the payment in kind, without converting it to cash, it does not often show up in the account. From 1504 to 1523 , the accounts show that the confraternity bought oil for the sanctuary lamp in addition to the rente payment. Between 1514 and 1522 , the parish paid one florin a year to the confraternity as a subvention of the lamp.

Beginning in 1524 , the confraternity accounts show purchases of garlands called "chapeals" to decorate the chapel on the feast of the Assumption. 
More permanent decoration of the confraternity's chapel also occupied its attention, especially in the early years. Several brothers in the confraternity, as well as outside workers, did major structural repairs on the chapel in 1468. In the $1480 \mathrm{~s}$, the confraternity decorated its chapel. Antoine le Pondeur, a confrere, painted and gilded the statue of the Virgin and the wall behind the altar; in 1480 , seven confreres contributed to buy seven "chapiteals" of copper. 26

Beginning in 1532, the confraternity engaged the choir of Saint-Paul to sing the Salve Regina every Saturday and Sunday. To help pay them, the confraternity took up a collection, but also paid a considerable sum out of the common fund. That a collection was taken shows that these services were meant to be, and in fact were, attended, probably by other parishioners as well as by confraternity members.

Thus the confraternity, through its devotional activitics, provided benefits for the whole parish. The chapel with its gilded and painted decorations, garlanded with flowers for major feasts, the lamp burning day and night before the tabernacle, the singing of the Salve Regina at Saturday and Sunday Vespers: these were things all the parish could appreciate.

The vicar and churchwardens appear to have understood the advantage to the parish of maintaining the confraternity. We have seen that the vicar took an active part in bringing about the union of the two original confraternities during the troubled time after the sack. Also during the late fifteenth century, some of the confraternity's property came from the parish, having been donated by the churchwardens to help the confraternity get back on its feet, especially to rebuild the chapel. ${ }^{27}$ This property was returned early in the sixteenth century. That the churchwardens would make such a donation shows the close relation of the confraternity to the parish. Just as the confraternity's chapel was part of the parish church, so too their patrimonics could be freely shared.

Although the versions of the rule dated after the union of the two original brotherhoods in 1473 drop the provision that superfluous goods should return to the parish, the confraternity's budget did in large part support the parish. The pricsts who celebrated the masses in the confraternity's schedule were mostly members of the parish staff. Only from 1507 to perhaps 1512 , when the Carmelite friars celebrated regular Monday masses, did the confraternity go outside the parish.

The connection of the vicar and chaplains went beyond merely celebrating the masses. Although the Confraternity of Our Lady was essentially a 
lay organization, there were always some clergymen in it. To begin with, the priest currently in charge of the parish, whether the vicar appointed by the chapter of Saint-Paul or his "lieutenant," was always a member. The other priests were either chaplains of the parish, like Johan Vaillant or Baldwin Charlier, or chaplains of Saint-Paul, like Ott Stratman or Johan Coreal, who also served in the parish. These were the priests who celebrated masses for the confraternity. It is not clear from the accounts whether or not priests were expected to pay dues. Some pay sometimes; almost all pay for their entry. The confraternity seems to have recognized a special role for the vicar. By rule, he said many of the confraternity's masses; the two vicars of the parish from 1492 to 1530, Cloes Jandelet and Cloes Jamart, approved the confraternity accounts each year. As with other members, the confraternity celebrated requiem masses for its priests.

The parish clerk, like the priests, received a salary from the confraternity for his services. While his name does not often appear on the membership lists, he enjoyed many of the privileges of membership. ${ }^{28}$ The parish clerk throughout most of this period was Godefrin Vaillant; his son, a priest, and later his widow, were also members. Antoine de Bealmont, a former parish clerk, was a member of the Confraternity of Our Lady throughout the 1480s.

Not only did the Confraternity of Our Lady include many members of the clergy on the parish staff, it also included almost all the lay leaders of the parish almost all the time. By including most of the churchwardens, tenants, and others who shared their responsibilities, the confraternity most visibly demonstrates its role as a framework for active lay participation in the life of the church.

Between 1480 and 1540 the parish of Saint-Martin-en-Ile had only six different churchwardens. Of these, five-Wilhem de Horion, Johan Grenier, Henri Paseal, Baldwin de Scagier, and Johannes Fabri-were all members of the confraternity. From 1488, all the churchwardens were confreres. When the documents give us the names of all seven tenants of the parish land court, we can see that that body was dominated by members of the Confraternity of Our Lady. In 1480, four of the tenants are also confreres; five in 1486; and six in 1497. At least six of the seven are members from then on. In 1525, all seven tenants (including the parish clerk) are members of the Confraternity of Our Lady. ${ }^{29}$

In addition to the churchwardens and tenants, there were other laymen who assisted in some way in the government of the parish. On certain occasions during the year, most often when the compteur presented his 
accounts at the end of the year, when the chaplains who celebrated regular masses received their assignments, and after the celebration of the anniversary of the dedication of the church, the parish staff and certain parishioners gathered for dinner. Since the dinner was paid for by the parish, it shows up as a notation in the accounts. Typically, the notation mentions the presence of the vestit, the chaplains (sometimes by name), the churchwardens, and the tenants (again sometimes by name). There are often several other names attached, followed by "and many parishioners." Those who are named we may call the parish "core."

Between 1480 and 1544, therefore, we can name 46 active parishioners, either churchwardens, tenants, or members of the core group. Of these, 35 were at some time members of the Confraternity of Our Lady. ${ }^{30}$ In 20 cases, the parishioners were members of the confraternity for several years before they appear in the parish accounts. Six joined the confraternity at roughly the same time as, and nine several years after, they are associated with the government of the parish. Moreover of the eleven who are not actually members of the confraternity, four probably have a confraternity connection, either as sons or husbands of women whose names appear in the confraternity rolls.

If we look only at the 21 most active parishioners, those whose names appear several times over a space of years, the correspondence is even more striking. Eighteen are present or future confreres; one is the husband of a long-time member; only two have no confraternity connection.

While almost all of the active parishioners were men, we should note that in 1520, "la femme Fanchon" attended the dinner on the anniversary of the dedication. She is probably Katherine Woet de Trixhe, wife of Johan de Fanchon and widow of the late tenant and confrere Johannes Saverot, and a member of the confraternity in her own right. ${ }^{31}$ While she is the only woman who appears in such a role in the parish, the notation of her presence on this occasion, as well as the connection of several other members of the core group through wives and mothers, reminds us that the parish was a network, not of individuals, but of families.

The sample with which we are dealing here is obviously too small and too haphazard for meaningful statistical analysis. What it yiclds is rather an impression, a picture of life in one urban parish. Membership in the confraternity was not a requirement for playing a role in the parish; but active parishioners tended to join the confraternity. They were also leaders in both: of 23 men who served as master of the confraternity from 1502 to 
1540 , the names of 16 also appear in the parish accounts. These 16 include 12 out of the 17 most active parishioners who were alive after 1502 . We cannot identify the leadership of the confraternity and the parish with one another, but the correspondence is close.

More helpful than statistics, perhaps, in clarifying our picture of parish life are the biographies of some of the men who served as churchwardens. There is enough information in the records to draw brief portraits of three churchwardens, covering the end of the fifteenth century and the beginning of the sixteenth: Wilhem de Horion, his son-in-law Henri Paseal, and Baldwin de Scagier, the progenitor of a family later important in the history of Liège.

Wilhem de Horion, a notary and a member of the mercer's guild, is responsible for much of our knowledge of the early history of the confraternity and of the history of contemporary Liège. After the liberation of the city from the Burgundians in 1477, he took up the office of rentier of the guild, in which capacity he recorded the circumstances of the guild's reestablishment, the only record of its kind that survives. ${ }^{32}$ In addition to this job, he was compteur of the Premonstratensian abbey of Beaurepart, of the Hôpital Saint-Jacques, and of the parish of Saint-Martin-en-Ile, a churchwarden of the parish and a member of its court of tenants, as well as a member and clerk of the court of tenants of the collegial church of Saint-Paul. ${ }^{33}$

It is no wonder that in describing how he accepted the job of compteur of the Confraternity of Our Lady, he wrote, "and I accepted their request notwithstanding that I had enough to do." ${ }^{34}$ Horion was the first permanent compteur for the confraternity, but his tenure beginning in 1480 was not the first time he had filled this role. In 1468, the Confraternity of Our Lady had put the accounts in his hands to oversee the repairs to their chapel. ${ }^{35}$

The case of Henri Paseal not only provides a portrait of a sixteenth-century lay leader, it also illustrates the network of marriage alliances that united the parish community. His entry into the confraternity very likely followed soon after his first marriage to Wilhem de Horion's daughter, Jehenne. Like Horion, he was a member of the mercers' guild; he joined his father-in-law on the court of tenants of the parish by 1497, and soon succeeded him as churchwarden. From this marriage he had three daughters. ${ }^{36}$ After his first wife died, he married Christine, widow of a confrere and fellow tenant of the parish, Lambert de Hermée the baker, who had just died, making Henry executor of his estate. ${ }^{37}$ In addition to his office 
as churchwarden, Paseal was compteur of the Hôpital Saint-Jacques from 1498 to 1523 , another office in which he succeeded his formidable fatherin-law. ${ }^{38}$ He served as master of the confraternity in 1515-17, 1520-22, and 1531-34, as many years as anyone else during this period.

Baldwin de Scagier, a churchwarden for many years and a confrere from before 1502 to his death in 1535, seems to have been, with Henri Paseal, one of the pillars of the parish in the early years of the sixteenth century. Unlike Paseal, he had numerous children. Only one followed him in the confraternity, Baldwin, called de Barbeal. Four entered religious life: Collard at the monastery of Saint-Jacques, Jchan at the Carmelites, Paulus as a brother in the hospice of Cornillon, and Gerard as a chaplain in the collegial church of Saint-Paul. This last son was also a chaplain in the parish, but he died young. In a note in the accounts of Saint-Martin-en-Ile, of which he was compteur at the time, the bereaved father mentions a donation of vestments which had belonged to "Messir Gerar nostre fis que Dieu pardon." 39 His eldest son, Heuskin, a vintner like his father, moved to the centre of town and became rentier of the coopers' guild; Baldwin, who stayed in the parish, practiced the same trade and served as guild governor. ${ }^{40}$

Both Baldwins, father and son, are referred to in records originating outside the parish as "Baldwin de Halighen." Both served in the city government as one of the "commissaires de la Cité" who played a role in the election of burgomasters and in maintaining public order. A third Baldwin followed them at the end of the century; his son Jean de Halinghen served as burgomaster in 1623 , and played a role in the revolt of the Grignoux that divided the city in this period. ${ }^{41}$

One may ask if these were simply the wealthiest or most politically influential men in the parish. In the absence of census or tax records, it is hard to estimate exact or even relative wealth. The members of the Confraternity of Our Lady included working tradesmen as well as merchants, lawyers, and investors. Maître Giles de Fanchon, later an échevin of the city and thus one of the highest officials of both the city and the principality, had occasionally represented the parish in court, but he was never a member of the confraternity. His widow joined immediately after his death, in 1520. While we may count him as one of the active laymen of the parish, his role was entirely professional. After he became an échevin in 1513, he ceased to work for the parish, and another lawyer took his place. ${ }^{42}$ Other men whose names appear as tenants or members of the core group 
and on the confraternity rolls performed other services, from accounting to construction work.

Most of the churchwardens, tenants, and others occupied the same social level as Wilhem de Horion and Baldwin de Scagier: merchants or professionals, owners of property, and holding minor offices. Some may have been making a fortune, so that their descendants might achieve the highest offices, as Scagier's great-grandson did; but they had not yet risen out of the parish. Their ties remained there: Baldwin de Scagier distinguishes a number of his fellow parishioners in his accounts by calling them "mon compere" and "ma commcre." Those like Maître Giles de Fanchon, whose sphere of action was the city or the principality, did not bother with the parish. It was a local world for local leaders.

Within the parish, the lay leaders, especially the churchwardens and tenants, had more than an occasional or ceremonial function. In both major decisions and the day-to-day functioning of the parish, they had an active and decisive role. Because the records of Saint-Martin-en-Ile contain rules for some of the operations of the parish church in the redundant Liégeois prose and firm notarial hand of the invaluable Wilhem de Horion, we know how they were supposed to function. The accounts show them in action.

The first of the two rules spells out the procedure for election of churchwardens. ${ }^{43}$ The second begins by providing for keeping the books and rendering accounts, but deals mainly with the appointment and payment of chaplains. ${ }^{44}$ These are to be chosen by the vicar and churchwardens, the vicar voting first, followed by the senior, then the junior, churchwarden-"and whatever two of them agree the third cannot and must not disagree with it later." 45 That is, the vicar might be outvoted by the churchwardens. Since when the vicar was an absentee, his replacement was one of the chaplains, this often amounted to allowing the parish representatives to choose their own pastor.

Evidence of the churchwardens in action also begins with Horion's records. The sack of Liège by Charles the Bold in 1468 greatly upset the life of the parish. The church itself was plundered, in spite of Charles's orders to spare all churches, the population was scattered, and the property on which the parish depended for its income was destroyed. ${ }^{46}$ The payments due became almost entirely uncollectible. ${ }^{47}$ The church building itself had been profaned by the troops, and had to be reconciled and reconsecrated by the auxiliary bishop before it could even be used. ${ }^{48}$ The accounts 
mention ornaments, vessels, vestments, and liturgical books which had to be recovered or replaced.

Shortly after the feast of St. Martin, 1472, the vicar and churchwardens met over dinner and made an agreement concerning the effects of the "devastation et rwin [sic] des guerres et arsin" in the parish. The principal problem was that the damage to the church and its property had left little income in the mass fund; moreover, the vicar had suffered similar losses. Therefore, the churchwardens, Piron le Berwier and Wilhem de Horion, instead of hiring chaplains, transferred four masses a week, with their income of twenty muids of spelt a year, from the budget of the mass fund to the vicar until such time as the vicar no longer had need of them. 49

By 1474 , conditions had improved somewhat. The churchwardens note in their register that the vicar had so many masses to say that he needs a chaplain. The mass fund, however, was still encumbered with bad debts, there were not enough linens, and there were "aultres indigenches apparentes." They conclude with a statement directed to their pastor, Jehan Thomas:

And we hope that you will behave as a good pastor ought to do, and take counsel and example from Master Tristan, former vicar of SaintNicolas, from the vicar of Saint-Jean-Baptiste, and from many other good rectors and pastors who put more into their church than they take out. ${ }^{50}$

Horion and Berwier provide us here with a precious example of fifteenthcentury laymen lecturing their pastor on his duties to use wisely the goods with which they and their predecessors have endowed the parish. Their successors, including Henri Paseal, Baldwin de Scagier, and their confreres like the lawyers Raes de Laminnes and Piron Hannoton, the brewer and commissaire Simon Damerier, and Collard and Jan de la Barbe d'Or, actively continued to help direct the affairs of the parish. The accounts bear witness to this activity. In recording purchases and transactions, the compteur often notes the presence-and for important ones the consent-of one of the churchwardens or tenants. Likewise when the parish consults its lawyers concerning lawsuits, it is the same officials who meet. It is safe to say that the secular affairs of the parish as an institution are firmly in the hands of laymen.

Nor did they make a distinction between secular and ecclesiastical affairs. Every parish was subject to visitation by the local archdeacon, in the case of urban parishes in Lic̀ge, the provost of the cathedral. When such a 
visitation impended in 1510, the lay leadership of Saint-Martin-en-Ile, for practical reasons, saw fit to avoid it:

Item, paid in the year [15]10 by the counsel of Henri Paseal and [Piron] Hannoton to our vicar for the first payment to the provost of Liège because of the visitation and to avoid greater expense if he had come in person: 3 florins 6 aidants ${ }^{51}$

In the matter of outside interference at least, layman and cleric were of one mind.

Most of the activities mentioned in the accounts belong to the routine of parish business: buying supplies, paying for services, and so on. Few were remarkable in themselves, but in cumulative effect they demonstrate an active lay community minding its own affairs. It also took care of its own: the same leaders who managed the general fund and the mass fund also managed poor relief. While most notations of how this occurred are vague and laconic, there is evidence that the pillars of the parish acted as neighborhood leaders in this field as well:

Item, Christmas night [1521] given to Jehan le Cock in his neighborhood, Piron de Sirar for the Treit. Henri Paseal for the Rue du Pont d'Avroy, Gilet le Mounier and me [Baldwin de Scagier] for the Vinâve d'Ile, the parish clerk and the sexton, distributed by each named above to the neediest poor: 1 aime of wine. ${ }^{52}$

Of those named here, all are among the most active parishioners. De Sirar appears never to have been a member of the confraternity; Gilet's father (also Gilet) had been a member until his death and his mother still was one in 1521. Jehan le Cock, a well-to-do coppersmith, was, like Scagier and Paseal, a faithful confrere and twice confraternity master.

Thus Saint-Martin-en-Ile had a group of active and committed lay leaders who were responsible for its affairs. Most of these leaders were also members of the principal confraternity of the parish, a confraternity which as a group, by its original rule and ongoing activities, served to strengthen the parish by ceremonial demonstrations of loyalty and by material support. Lawrence Duggan alludes to this kind of loyalty and support in his important article, "The Unresponsiveness of the Late Medieval Church: A Reconsideration," when he writes, "Far from withdrawing or being alienated from the established church, laymen in the late Middle Ages were in every way deeply involved in it." 53 He notes the increased attention paid to the local parish in the late Middle Ages, a period which in Liège must be extended through 
at least the first half of the sixteenth century. ${ }^{54}$ The case of Saint-Martinen-Ile shows just how deeply they were involved.

Moreover, it clearly contradicts the view of Le Bras that everywhere the parish and the confraternity were at odds. Here the confraternity was the expression of lay involvement in the very structures of the establishment. To return to Trollope's observation, "in religion as in everything else, men like to manage themselves": in the late Medieval parish, the confraternity provided the means for self-management. If it formed, in Le Bras's term, a "consensual parish," it did so not in opposition to, but rather for the sake of, the official parish. Confraternal brotherhood presented an ideal that could be reflected in the parish community where the clergy were not so much the rulers as the sons, brothers, neighbors, and colleagues of the laity.

\section{Ann Arbor, Michigan}

\section{Notes}

1 Anthony Trollope, The Vicar of Bullhampton (1870), The World's Classics ed. (London: Oxford University Press,1924), p. 306.

2 "Mais tout le temps la confrérie a inquiété l'Eglise par son indépendence naturelle et désordres fréquents. Elle constitue au sein ou au-dessus de la paroisse légale une paroisse consensuelle, avec son oratoire, son clergé, son culte, son patrimoine. D'où la concurrence des offices, des caisses, des influences. D'où les conflits avec le curé, avec la fabrique, toujours latents et qui éclatent en épidémies." Gabriel Le Bras, Etudes de Sociologie Religieuse (Paris: Presses Universitaires de France, 1955-56), p. 454.

3 For examples, see Giles-Gerard Meersseman, "Etudes sur les anciennes confréries dominicaines. Les Confréries de Saint Dominique," Archivum Fratrum Praedicatorum 20 (1950): 5-113.

4 Jacques Toussaert, Le Sentiment religieux en Flandre à la fin du moyen âge (Paris: Plon, 1963), pp. 122-204.

5 John Bossy, "The Counter-Reformation and the People of Catholic Europe," Past and Present 47 (1970): 53.

6 John Bossy, Christianity in the West, 1400-1700 (New York: Oxford University Press, 1985).

7 Martine Segalen, Les Confréries dans la France contemporaine. Les Charités (Paris: Flammarion, 1975), pp. 105-106.

8 Ibid., pp. 116, 187-89; cf. Bossy, "The Counter-Reformation and the People."

9 John Van Engen, "The Christian Middle Ages as an Historiographical Problem," American Historical Review 91 (1986): 536.

10 Ibid., p. 544.

11 The description of the parish is largely based on Léon Lahaye, "La Paroisse Saint-Martin-en-Ile à Liège," Bulletin de la socièté d'ant el d'histoire du diocèse de Liège 25 (1934): 25-130, as corrected by evidence from the archives.

12 Etienne Hélin, La Population des paroisses liégeoises au XVIIe et XVIIIe siècles (Liège: Commission communale pour l'histoire de l'ancien pays de Liège, 1959), p. 234.

13 On the parishes of Liège in géneral, see Léon Lahaye, "Les Paroisses de Liège," Bulletin de l'Institut archéologique liégeois 46 (1921): 1-208; see also Paul Adam, La Vie paroissiale en France au XIVe siecle (Paris: Sirey, 1964). 
14 The word mambour means "guardian"; while in parish usage it generally means "churchwarden," it could also be used in one of its more general senses to mean a retained attorney at law (in full mambour en justice). The accounts of the parish usually do not call this man a mambour directly, but refer to paying someone "pour sa mambournie."

15 The use of tenants was not limited to the parishes; it was an integral part of the legal system. Any institution, for that matter any private individual who owned property, had to be able to "hold court" in order to receive reliefs of property, the payments made by a new tenant after inheritance or purchase (see Godefroid Kurth, La Cité de Liège au moyen áge (Brussels: Dewit, 1909-10), 3: 382). Most private persons "borrowed" an already existing court, or acted before the court of the échevins, but the endowed ecclesiastical institutions of Liège had permanent courts of tenants who received a salary for their services. The courts resembled in form and in function the court of échevins; they not only recorded property transfers and reliefs, they originally could hear lawsuits relating to property held under them. This latter function, however, had largely passed to the échevins by the fifteenth century.

16 The list of pastors is given in Lahaye, "La paroisse Saint-Martin-en-Ile," pp. 95-101. See Appendix A for a detailed list.

17 Archives de l'Etat, Liège [hereafter AEL], Saint-Martin-en-Ile, reg. 50, f. 153.

18 A more complete account of the Confraternity of Our Lady is to be found-in D. Henry Dieterich, "Brotherhood and Community on the Eve of the Reformation: Confraternities and Parish Life in Liège, 1450-1540," (Ph.D. dissertation, University of Michigan, 1982).

19 Confrérie de la très-sainte Vierge érigée dans l'Eglise Paroissiale de saint Martin en Isle à Liège l'an 1457 \& renouvellée l'an 1736... (Liège: L. J. Demany, 1792).

20 AEL, Saint-Martin-en-Ile, charte de 23 août 1457; AEL, Saint-Martin-en-Ile, charte de 5 juin 1461; AEL, Saint-Martin-en-Ile, reg. 125, $\Upsilon$. 1-2v.

21 AEL, Saint-Martin-en-Ile, reg. 123, ff. 7-11v. This version of the rule accompanies the charter of approval granted by Jean de Hornes, provost of Liège, 19 June 1529.

22 Cf., for example, A.N. Galpern, Religions of the People in Sixteenth-Century Champagne (Cambridge: Harvard University Press, 1976), pp. 46-48.

23 Space does not permit a complete review of the liturgical calendar of the confraternity. After the two original confraternities were united, the Confraternity of Our Lady maintained all the masses called for in the schedule of both. The principal mass and the banquet were held on the feast of the Assumption.

24 AEL. Saint-Martin-en-Ile, reg. 125, f. 7v.

$25 \mathrm{Ibid}$., reg. $125, \mathrm{f} .8 \mathrm{v}$.; the wars to which the accounts refer are probably those surrounding the revolt of the La Marck, since the compteur (Wilhem de Horion) speaks of them as going on at the time he is writing (1480).

26 Ibid., reg. 125. f. $22 \mathrm{v}$.

27 Ibid., reg. 125, f. 32.

28 In the 1480s, the accounts show that he attended the banquet at the confraternity's expense; in 1523 his daughter received a confraternity funeral (AEL, Saint-Martin-en-Ile, reg. 128, f. 22).

29 AEL, Saint-Martin-en-Ile, reg. 14l, ff. 50, 91v, 98v, 113v, 117v, 120; added signature, f. 4.

30 See Appendix B for a tabular presentation.

31 The sad story of Katherine Woet de Trixhe appears in Dieterich, "Brotherhood and Community," pp. 165-67.

32 The original document was damaged in a fire in the archives caused by a German bomb in 1944. Fortunately most of it was published in the Régestes de la cité de Liège, ed. Emile Fairon, vol. 4 (Liège: Commission communale pour l'histoire de l'ancien pays de Liège, 1939), pp. 370-71. 
33 AEL, Saint-Martin-en-Ile, regs. 41, f. 64, 43, f. 79, 44, f. 113v; Hôpital Saint-Jacques, ptf. 7; Archives de l'Evêche, Liège, reg. C.VII.21, f. 45v.

34 "Et je a leur request lay accepte nonobstan que avoy asses affair." AEL, Saint-Martin-en-Ile, reg. 125, f. 8.

35 AEL, Saint-Martin-en-Ile, 128, f. 5.

36 AEL, Echevins de Liège, Convenances et Testaments, reg. 27, ff. 33v-34.

37 AEL, Echevins de Liège, Convenances et Testaments, reg. 28, ff. 336-36v. Henri and Christine appear not to have had any children. In her will made in 1532 she left a house to Lambert's nephew and the rest of her estate to Henri (AEL, Echevins de Liège, Convenances et Testaments, reg. 32, f. 186-86v). She had previously settled Lambert's bakery on her son Loren, also a baker and a member of the Confraternity of Our Lady (AEL, Echevins de Liège, Oeuvres, reg. 113, గ. 140v-41).

38 AEL, Hôpital Saint-Jacques, ptf. 7.

39 AEL, Saint-Martin-en-Ile, reg. 50, f. 39.

40 On the elder Baldwin and his family, see Paul Ansiaux, "Grégoire Sylvius, inquisiteur et évêque auxiliaire liégeois (1502-1578)," Bulletin de la société d'art et d'histoire du diocèse de Liège 26 (1935): 1-20. Ansiaux's information concerning Baldwin de Scagier is accurate, except that he was not the father of Grégoire Sylvius. The error originates with Joseph Abry, Recueil héraldique des bourgmestres de la noble cité de Liège (Liège: J.P. Gramme, 1720), p. 358.

41 Abry, Recueil héraldique, p. 379.

42 Maître Giles working for the parish: AEL, Saint-Martin-en-Ile, reg. 46, f. 146; replaced, Saint-Martin-en-Ile, reg. 48, f. 45v. As échevin: Camille De Borman, Echevins de la souveraine justice de Liège, vol. I (Liège: D. Cormaux, 1899); widow in the confraternity: AEL, Saint-Martin-en-Ile, reg. 128, f. 9.

43 AEL, Saint-Martin-en-Ile, reg. 141, If. 153v-54.

44 Ibid., ff. 155v-57v.

45 "Et ce que deux deaulx trois acordent le terce nel puet ne icel doit debattre ensuvant." Ibid. f. 156.

46 Charles was excommunicated for this flagrant violation of the Church's immunity. In reparation, he presented a gold reliquary to Saint-Lambert, which is still part of the treasure of the cathedral of Liège. See Kurth. La Cite de Liegge au moyen age, 3: 350.

47 In the year 1464-65, the receiver was able to collect 56 percent of the rentes in spelt owing to the parish, counting old debts. For the three years from All Saints 1466 to All Saints 1469, three years of war and destruction which are figured together in the record, he was only able to collect 19 percent; see AEL, Saint-Martin-en-Ile, reg. 41 , ff. $11 \mathrm{v}-15$.

48 Ibid., I. $25 \mathrm{v}$.

49 Ibid., I. 64.

50 "Et esperons que en fereis com ung boen pasteur et en doit fair et predereis conseil et exemple a maistre Tristan jadis vestit de Sain Nicolay a vestis de Sain Jehan Baptiste et a plussieurs aultres boens cureis et pasteurs qui plus mettent a leur engleise que ilh ny prendent." Ibid., f. 87.

51 "Item paijet lan $x$ par le conseilh de Henri Pasea et Hanuton a nr vestit par le premier paijement de prevo de Liège a cause de visitacion et pour eviter plus gran despan sil ewiyst venu en person 3 ก 6 aid." $A E L$, Saint-Martin-en-Ile, reg. 46, f. 40.

52 "Item le nuit de Noel donne a Jehan le Cock en son quartier, Piron de Sirar por le Treist Henri Pasea por le Rue du Pont dAvroy, Gilet le Mounier et moy en Vinave dIle Marlir et Fossier par icheux chy deseur nomme distribuent a plus nessare pouvres -1 ayme de vin." AEL, Saint-Martin-en-Ile, reg. 50, f. 106v.

53 Lawrence Duggan, "The Unresponsiveness of the Late Medieval Church: A Reconsideration," Sixteenth Century Journal 9, no. 1 (1978): 8.

54 Ibid., p. 9. 


\section{APPENDIX A: Vicars of Saint-Martin-en-Ile}

Jehan del Seny served from 1426 to 1459 . He was dean of the Confraternity of Thirty Priests, which assembled all the pastors of Liège, in 1446 and 1447. He ended his days, some time before 1470 , as a canon and cantor of the collegiate church of Sainte-Croix. ${ }^{1}$

Jehan Thomas succeeded him in 1460 and served until his death in 1475.

He was in turn succeeded by a cleric known to us as Henricus de Puteo, ${ }^{2}$ who may never have set foot in the parish. He was not a priest but a student of theology at Louvain. Lynar Fachin, ${ }^{3}$ who had been a chaplain under Jehan Thomas, served as "lieutenant" until he died in 1482. The vicar then appointed Gilles le Damoiseau ${ }^{4}$ who served until 1486 and was succeeded by Johan Hanuton. ${ }^{5}$

Nicolas Jandelette (or Gondelet), also called Cloes de Builhon, served as resident vicar until his death in December 1520. We know little of his origins, except that his mother lived in the parish. ${ }^{6} \mathrm{He}$ was appointed by papal provision rather than by the dean and chapter, and had to fight a lawsuit to take possession finally in 1492, after which he had to pay a pension of 20 florins a year to a certain Johannes Billiton.

Nicolas (Cloes) Jamart succeeded Jandelette in 1522, after litigation that left the office vacant for over a year. Jamart, whose uncle had been vicar of the neighboring parish of Saint-Adalbert, had been rector in the village of Jeneffe before coming to Saint-Martin. ${ }^{8}$

Jacques Alberti succeeded briefly in 1530. but he died almost at once.

Antoine de Hertoghe, 1530-1533, a canon of Saint-Paul, did not serve in person.

Charles de la Tour, de Hertoghe's successor, a canon of Saint-Jean-Evangéliste, did not serve either.

1 AEL, Saint-Martin-en-Ile, reg. 5, f. 32.

2 Lahaye, "La Paroisse Saint-Martin-en-Ile," p. 98, calls him "Pierre" but cf. AEL, Prévôté, reg. 26, f. 130.

3 AEL, Saint-Martin-en-Ile, reg. 44, f. 21.

4 Lahaye, "La paroisse Saint-Martin-en-Ile," cf. AEL, Saint-Martin-en-Ile, reg. 125, f. 30.

5 AEL, Saint-Martin-en-Ile, reg. 44, f. 320.

6 AEL, Saint-Martin-en-Ile, reg. 127, f. 26.

7 AEL, Prévôté, reg. 34, f. 22v; but he was recognized in the parish in 1490: see AEL, Saint-Martin-en-lle, reg. 45 , f. $33 \mathrm{v}$.

8 AEL, Echevins de Liège, Oeuvres, reg. 53, ff. 306v-307. 
APPENDIX B: Confraternity membership and parish participation

\begin{tabular}{lcc}
\hline & $\begin{array}{c}\text { Total active } \\
46\end{array}$ & $\begin{array}{c}\text { Most active } \\
21\end{array}$ \\
\hline $\begin{array}{l}\text { Confraternity } \\
\text { members: } \\
\quad \text { of whom: }\end{array}$ & 35 & 18 \\
$\begin{array}{l}\text { joined before } \\
\text { they appear in } \\
\text { the parish books: } \\
\begin{array}{l}\text { joined at about } \\
\text { the same time } \\
\text { they appear: }(1)\end{array}\end{array}$ & 20 & 11 \\
$\begin{array}{l}\text { joined after } \\
\text { they appear: } \\
\text { [served as master } \\
\text { in the confraternity: }(2)\end{array}$ & 18 & 2 \\
\hline $\begin{array}{l}\text { Non-members: } \\
\quad\end{array}$ & 11 & 5 \\
$\begin{array}{l}\text { of whom: } \\
\text { had some family }\end{array}$ & 9 & $14]$ \\
$\begin{array}{l}\text { appear to have } \\
\text { no connection: }\end{array}$ & 7 & 3 \\
\hline
\end{tabular}

1 "About the same time" means within one year before or after.

2 The records of the confraternity, including the names of the masters, are sketchy before 1502. More of the early confreres may have been masters during this time.

3 Probable family connections: Barthelemy de Pepenge, husband of Katherine de Pepenge, confraternity member 1512-47 and daughter of the confrere Francheu de Laitre; Lambert d'Heur, son of Aelid d'Heur (widow of Christian Gheister), a member 1482-1527. Gilet le Mounier and Maitre Giles de Fanchon, see text. 